\title{
Planning Strategically for Small Libraries
}

Susan Ebertz, Wartburg Theological Seminary

Karl Stutzman, Anabaptist Mennonite Theological Seminary

ABSTRACT Strategic planning is important for small theological libraries. Strategic planning allows libraries to identify goals and succeed in completing them. Unfortunately, there is often very limited staff time at small libraries, so librarians default to simply "doing" rather than planning. The presenters discussed some of the background of strategic planning and emphasized the importance of purpose statements and strategic plans for accreditation and evaluation. They also identified barriers to planning in their own libraries and offered practical advice for working on strategic plans with limited time and resources. Additionally, they emphasized the value of thinking strategically, which may be even more important than creating and executing a detailed strategic plan.

\section{BACKGROUND}

Strategic plans are vital to give direction for theological libraries. At many small theological libraries, much of the time is spent in doing. Planning becomes a lower priority and is pushed to the side. Strategic planning and ongoing evaluation may help focus the many activities and services that small libraries do. Let's go over our learning outcomes for the session:

- Participants will find out about resources to help them in creating their own strategic plan with efficiency.

- Participants will be able to relate the experiences of the panelists to their own experiences and contexts.

- Participants will be able to assess their own context and appropriately develop their own practical approaches.

Strategic planning started out as a corporate idea in the 1960s. By the 1980s, it had moved into the nonprofit world, in part through the influence of John M. Bryson's Strategic Planning for Public and 
Nonprofit Organizations. Strategic planning typically looks at a longer-term future, sets priorities and goals, and allocates resources to meet the priorities and goals. Bryson writes that "strategic planning may be defined as a disciplined effort to produce fundamental decisions and actions that shape and guide what an organization (or other entity) is, what it does, and why it does it" (Bryson 1995, x).

Small is a relative term. So what are small theological libraries? Basically, if you think of your library as small, you qualify! Many times, when we think of this designation, we are considering staff size: one or two staff members. Librarians from small libraries often go to conferences like Atla Annual and admire what larger libraries with more staff can accomplish, but can't realistically do it. There is another side to being small though: being small can also be beautiful in terms of the opportunities for creativity and flexibility in management.

To begin with, it will be important for you to understand our contexts and how we are small libraries.

Susan is at Wartburg Theological Seminary in Dubuque, Iowa, USA. Wartburg has about 180 students FTE. We have three masters' programs: the MA, the MA-Diaconal Ministry, and the MDiv. About $2 / 3$ of Wartburg students are distance students. The library staff includes a paraprofessional, 36 hours of students per week, and one professional librarian. Wartburg has around 100,000 print volumes and over 525,000 e-books through the Digital Theological Library.

Karl is at Anabaptist Mennonite Biblical Seminary, which is located in Elkhart, Indiana, USA. It has about 100 students in MA and MDiv programs, with both distance and campus options. Two librarians manage a library of over 100,000 print volumes and lots of electronic content.

In this session, we will be discussing our mission/purpose statements and planning and assessment. For a bit of additional context, statements and planning may not be optional anymore! Many Atla libraries are also members of the Association of Theological Schools (ATS), which accredits graduate programs in theological disciplines in the US and Canada. ATS is currently in the process of revising its standards. New standards are due for final approval at the ATS biennial meeting later this month (June 2020), including a section on libraries. The library standard includes a new emphasis on planning and evaluation. The very first substandard mandates libraries at ATS institutions to have "a clear statement that identifies its purpose and 
role in the school and the ways it contributes to achieving the school's educational mission." Further, this purpose statement "forms the foundation for evaluating library and information services." The standard calls for library personnel to have a role in the school's decision-making processes, "including budgeting and strategic planning." The standard also calls for library personnel to "regularly evaluate the adequacy and use of its services and resources" (ATS 2020, 10).

\section{IMPEDIMENTS AND POTHOLES}

For small libraries, there are a series of impediments to strategic planning. As mentioned in our session description, small libraries often spend time "doing," leaving little time to plan. This is related to Charles Hummel's (1994) concept of "the tyranny of the urgent," in which we tend to urgent matters rather than what is truly important. Or it could be that we are on autopilot: we hand over control of our actions in the library to outside forces and allow them to control our future.

Potholes are created when certain factors in the environment are present. They make travelling down a road more difficult. Here are the potholes Susan experienced as she attempted to create a strategic plan.

- Administration wants a re-do. She began working on a strategic plan during the 2017-18 school year. The administration wanted to see plans for the "future of our library." She formed a committee of students and faculty to work on this. They created a plan, but Susan was told by the administration that it needed to be reworked. Back to the drawing board, but then she went on sabbatical spring semester 2019.

- Change in leadership. Wartburg's president announced her departure and left at the end of December 2019. AMBS also faced a change in leadership at the top. As you know, change in leadership could mean change in direction, focus. Back to the drawing board.

- COVID-19. Do I need to say more? The pandemic changed our lives in many ways. Strategic planning was not a top priority this spring. There was no time to go back to the drawing board.

- New institutional strategic plan. Though Susan's school is still in the presidential search process, her school approved a new 
strategic plan. All their plans have been two-year plans with modified or new goals. The plan is evaluated annually. The plan Susan was working on needed to be reworked to take into account the new and modified goals. Back to the drawing board.

So how do we move past these impediments and potholes to actually doing something about our strategic planning? Taking time away from your regular duties for this session may be a start. Part of this session was discussion about how librarians can actually apply this in their own libraries. One thing Karl has been doing is keeping the goal of doing strategic planning work "alive" in his meetings with the dean, his supervisor, who can hold him accountable for making progress.

\section{MISSION AND PURPOSE STATEMENTS}

A first step toward strategic planning in much of the literature is identifying a mission or core purpose statement for your library. AMBS has had this mission statement since a previous round of strategic planning by librarians in 2010:

The AMBS Library promotes the use of information resources to advance the AMBS mission of serving the church and educating leaders for God's mission in the world. As a center of scholarship, reflection and lifelong learning, the Library provides professional services, relevant collections, and a hospitable study environment for AMBS students, faculty, staff, and church leaders. (Stutzman and Saner 2016)

At 10 years, it's due for re-evaluation. Karl has thought about reframing it as a "core purpose" statement after talking with another librarian and reading the book Good to Great by Jim Collins (2001). However, the AMBS statement still covers the basics of the library's role, so they might end up just tweaking it slightly and reaffirming it. Karl suggests, based on prior experience and some reading on library mission statements, that it's best to collaborate to generate ideas and have one person write the statement itself based on those ideas so that you're not writing by committee. One of the things Karl found in his research on mission statements is that they can serve multiple purposes, like marketing the library or communicating an aspirational vision for the future. Some sources suggested a mission statement that could be printed on a coffee cup and memorized! For most small theological libraries, though, printing mission state- 
ments on coffee cups is not going to happen. For the AMBS library and many others, signaling alignment with institutional mission is going to be a primary consideration, especially since the ATS standard indicates our purpose and role in the school (ATS 2020,10). The AMBS library mission statement displays that institutional alignment in the first sentence.

Wartburg Seminary has had this mission statement for a long time:

The Reu Memorial Library serves the mission of Wartburg Theological Seminary by supporting the educational activities of the institution; providing a place for independent and collaborative learning for all WTS students; collecting, preserving, organizing, and offering resources in a variety of formats; and teaching and equipping the WTS community for lifelong spiritual, intellectual, and personal learning. (Wartburg Seminary n.d.)

Wartburg periodically looks at its mission statement to see if it is still relevant. They have made some tweaks. The basic points are 1) support the mission of the school, 2) place (both physical and virtual), 3) resources, and 4) teaching.

As you think about creating your mission/purpose statement there really are three basic elements that you need: supporting the mission of the school, services, and resources. If you are like Susan and find it difficult to come up with a statement, borrow someone else's statement and make it your own. Make sure it names your services and resources and supports the mission of your school! Don't prolong the agony by trying to come up with the perfect statement. You don't have the time.

\section{PLANNING AND EVALUATION}

Soon-to-be ATS standard 6.1 states that the library's purpose statement forms the foundation for evaluating library and information services. That means that, as we think about strategic planning, the next step after creating our mission/purpose statement is to figure out how we will evaluate it. Evaluation should always be a part of the planning cycle. Plan, implement, evaluate, plan.

Susan created goals for each of the points of her library's mission statement. For example, under place, the goal was to create a virtual place for students. Since they have so many distance students, she needed to figure out a "place" for them. To fulfill that goal, they created a library LMS site. Students go to the LMS for their classes. If 
they need the library, she wanted it to be easy for them to just switch to the library and get what they need. The library LMS site had to be easy to use and include what they needed. This was not a high priority until COVID-19 hit. Then it became a very high priority. All students would be accessing the library via the site. The student she had working on this no longer had other tasks.

The new ATS standards talk about the purpose statement being the foundation for evaluating library and information services. Taking Susan's example of the library LMS site, she created it to be a virtual place for students. In order to evaluate it, she needs to find out the adequacy and use. The ATS mantra is "simple, sustainable, sufficient." So how does she make this simple, sustainable, and sufficient? Susan doesn't want evaluation to be complicated. She doesn't have time for that. Since it is an LMS "course," she can tell if students are logging into it. She could capture information at the end of a semester or she could take a sample at various times of the semester. They received questions from students about the site. This helped them to make edits which made the site more helpful and clearer. The evaluation fed back into changes.

Creating something similar to Karl's "Strategic Planning Workbook" is also a great way to evaluate.

\section{PRACTICAL TIPS FOR STRATEGIC PLANNING}

Strategic planning can be an exercise in futility. Brian Mathews, in his 2012 whitepaper, "Think Like a Startup," urges librarians to "build a strategic culture, not a strategic plan." He writes that "many library strategic plans read more like to-do lists rather than entrepreneurial visions." While Karl thinks that Mathews is a bit extreme, especially for small libraries with limited resources, he thinks it's wise to remember not to document every last to-do and instead focus on the big picture of where you want to go.

The strategic planning process can be as important for building a strategic culture as the plan itself. Michael Allison and Jude Kaye, in their book Strategic Planning for Nonprofit Organizations : A Practical Guide for Dynamic Times (2014), state that the strategic planning "process is about building alignment and commitment" and emphasize engaging stakeholders in the planning process. Getting buy-in from a library advisory board or task force is critical to a successful plan. Allison and Kaye state that increasing impact means "growing 
in one or more ways." Either that is to do "more," which requires more resources, or it is to work differently, either through "process improvement," "design improvement," or "strategic improvement." Karl thinks part of this process improvement includes naming things you will no longer do as a library. This is harder than it seems! They also state that it's important to produce a document that is linked to budget and priorities as a way to guide the organization.

In their chapter "Mission Possible: Strategic Planning for Small Academic Libraries,” Darla Haines, Rebecca Johnson, Jill Lichtsinn, and Edita Sicken (2016), all from Manchester University, outline a number of helpful best practices for small libraries embarking on strategic planning. They include devoting even small amounts of time to plan, researching example plans, creating institutional alignment on mission and vision, setting clear goals and action items along with a timeline, creating a visual of the strategic plan, and reviewing it regularly. Karl knows Darla Haines as a fellow library director in the Private Academic Library Network of Indiana, so he checked in with her. Manchester's library has gone through major staff cuts since the chapter was written, and Haines advised not biting off more than you can chew in a strategic plan, making it become a "list of tasks no one has time to do." She recommended including some "stop doing" actions in the strategic plan as well.

For libraries that are part of a parent institution, such as a seminary or university, starting with the institution's strategic plan may be a helpful way to seek alignment and not have to plan from scratch. Karl has taken an early version of my institution's new strategic plan and identified library goals and action items that aspire to the same basic priorities my seminary is working toward. Karl's next step is to take these library goals and action items to the library advisory board to get buy-in and additional suggestions.

In preparation for his strategic planning work, Karl made a simple spreadsheet workbook with tabs for various stages of the planning process. This is “dumbed down" strategic planning, but Karl hopes it's adequate for a small library. The first tab is an engagement plan for stakeholders. It lists potential stakeholders in the first column (e.g., library employees, students, faculty, administrators, community members, alumni, consortial partners) and has space to include your plan for engaging them in the strategic planning process (second column) and the date for engagement (third column). 
The second tab is for environmental scanning and allows you to list strengths (first column), weaknesses (second column), opportunities (third column), and threats (fourth column), and references possible other documents to use in your environmental scan (fifth column).

The third tab is where you actually develop the strategic plan by listing priorities (first column), goals (second column), and action items (third column with at least one action item for each goal).

The final tab is a "dashboard." You copy the strategic plan onto this tab and use it to track progress (add a progress update in the fourth column) in terms of completing goals and action items (add a date completed in the fifth column).

\section{STRATEGIC THINKING}

The following quote is from Bryson (1995, x): "Strategic planning is useful only if it improves strategic thought and action; it is not a substitute for them." You may not have your mission statement completely formulated, but you need to start thinking about the elements of that mission statement. What is the purpose for your library? For most, they are resources and services for your students and faculty. If you know your end goal (your purpose) you can change the way you are getting to it.

Impediments and potholes get in the way. What do you do? How do you eat an elephant? One bite at a time. How do you get around a pothole? Carefully or take a different route.

A pandemic happens. What do you do? If you are thinking strategically, you know that you need to still provide resources and services for your students and faculty. Your method may change. But you know that your purpose/mission does not. If you have your purpose clearly in your mind, you can be creative and nimble. You can shift things easily because you know where you are headed.

The session then broke into small groups to talk about where each participant was in the planning process and how each will move forward (practical steps). 


\section{WORKS CITED}

Allison, Michael and Jude Kaye. 2014. Strategic Planning for Nonprofit Organizations: A Practical Guide and Workbook. Hoboken, NJ: John Wiley \& Sons.

Association of Theological Schools. 2020. Standards of Accreditation for the Commission on Accrediting of the Association of Theological Schools. Chicago: Association of Theological Schools.

Bryson, John M. 1995. Strategic Planning for Public and Nonprofit Organizations: A Guide to Strengthening and Sustaining Organizational Achievement. Revised first edition online resource. San Francisco: Jossey-Bass Publishers. site.ebrary.com/id/10114175.

Collins, Jim. 2001. Good to Great: Why Some Companies Make the Leap and Others Don't. New York, NY: HarperBusiness.

Haines, Darla, Rebecca Johnson, Jill Lichtsinn, and Edita Sicken. 2016. "Mission Possible: Strategic Planning for Small Academic Libraries.” In The Small and Rural Academic Library: Leveraging Resources and Overcoming Limitations, edited by Kaetrena Davis Kendrick and Deborah Tritt, 131-45. Chicago: Association of College and Research Libraries.

Hummel, Charles E. 1994. Tyranny of the Urgent. Revised \& enlarged edition. IVP Books.

Mathews, Brian. 2012. "Think Like A Startup: A White Paper to Inspire Library Entrepreneurialism.” Working paper. vtechworks.lib.vt.edu/handle/10919/18649.

Stutzman, Karl, and Eileen Saner. 2016. "Guides: AMBS Library Resource Access Policy: Philosophy of Resource Access.” libraryguides.ambs.edu/resourceaccesspolicy/philosophy.

Wartburg Seminary. n.d. "Reu Memorial Library.” Accessed July 13, 2020. www.wartburgseminary.edu/library/. 